\title{
FAILING THE SYSTEM? ENFORCING THE RIGHT TO EDUCATION IN NEW ZEALAND
}

\author{
E J Ryan*
}

At both the international and domestic level, the existence of a right to education is given widespread support. But what are the content and consequences of this right? The meaning of the right to education was examined recently in the context of special education by the High Court and Court of Appeal in Daniels v Attorney-General. The High Court saw the right as a substantive one; the Court of Appeal viewed it in procedural terms. These different conceptions of the right affected the remedies available to the plaintiffs. This article assesses the competing understandings of the education right in NZ, and concludes, particularly in light of the House of Lords' decision in Phelps v Hillingdon London Borough Council, that the High Court's approach is to be preferred.

\section{INTRODUCTION}

Internationally education is seen as an important right. This is acknowledged in several international documents. The Universal Declaration of Human Rights states: "Everyone has the right to education. Education shall be free at least in the elementary and fundamental stages. Elementary education shall be compulsory." 1 The International Covenant on Economic, Social and Cultural Rights emphasises that education enables "all persons to participate effectively in a free society, [and] promotes understanding, tolerance and friendship among all racial, ethnic or religious groups." ${ }^{2}$ The United Nations Convention on the Rights of the Child also emphasises the right children have to receive education, and states that there is a duty on the state to provide this. ${ }^{3}$ New Zealand's history of providing free education stretches back over 100 years, embracing the notions expressed in the international documents. Education is an important right, and is reflected in the

* Submitted as part of the LLB(Hons) programme at Victoria University of Wellington (supervisor: Bill Atkin).

1 Ian Brownlie (ed) Basic Documents in International Law (3 ed, Clarendon Press, Oxford, 1983) 255.

2 International Covenant on Economic, Social and Cultural Rights (16 December 1966) 922 UNTS 3, art 13.

3 United Nations Convention on the Rights of the Child (20 November 1989) 1577 UNTS 3, art 28. 
Education Act 1989 where free education is granted to all children. ${ }^{4}$ Education is an integral part of New Zealand society.

Given that education is held in such high regard in New Zealand, it is interesting that there appears no clear picture of what the right actually entails in a legal sense. There is widespread support of universal education for all $^{5}$ - statements in the international documents are not meaningless epithets but are intended to have concrete effect. Debate on the content of the right has occurred most clearly in negative contexts, that is, when concerns have arisen that the right may not have been fulfilled. This foreshadows a parallel question: if the right to education can be described at least in minimum terms, can it then be enforced? Can the courts be expected to give meaning and corresponding protection to it? There seems a tacit assumption that there will be no need to uphold the right; education of an appropriate standard will be delivered to everyone. ${ }^{6}$ A long-standing and much celebrated legal principle states that where there is a right, there ought to be a remedy. ${ }^{7}$ If there is no clear path for redress, it is questionable whether an effective and enforceable right to education exists in New Zealand.

This article explores the nature and enforceability of the right to education within the context of special education in New Zealand. There are several reasons for this. First, education for special needs students is an important element of the commitment to education for all children. The New Zealand government has recognised the importance of special education, developing the Special Education 2000 (SE2000) policy in order to develop a world-class inclusive system of education. ${ }^{8}$ It is, however, a highly contentious area with resources stretched to provide for students with a huge variety of special needs. The policy also has broader effects on the families of special needs students. It is therefore an area where concerns and disputes are likely to arise, and thus provides fertile ground in which to base a discussion of what the right to education actually entails. If there is a substantive right to education in New Zealand, it is of vital importance that children with special needs receive its benefits.

Secondly, it is an area that the courts have considered. In New Zealand the SE2000 policy has been subject to recent judicial review, the judgment in Daniels $v$ Attorney-General ${ }^{9}$ having been released in February 2003. In the UK special education has been recognised, albeit in the field of

4 Education Act 1989, s 3.

$5 \quad$ Note that all political parties across the spectrum agree on this point.

6 Sally Varnham "Liability for Little Learning: An Examination of the Potential for Educator/Student Liability in the Compulsory Education Sector" (LLM Thesis, Victoria University of Wellington, 1998) 47.

7 Ashby $v$ White (1703) 2 Ld Raym 938; 92 ER 126 Holt CJ.

8 Ministry of Education Special Education 2000 (May 1996) 5.

9 Daniels v Attorney-General (3 April 2002) HC AK M1516/SW99; Attorney-General v Daniels [2003] 2 NZLR 742 (CA) ["Daniels"]. 
negligence, in Phelps $v$ Hillingdon London Borough Council. ${ }^{10}$ Both cases provide insight into what a right to education might entail. The discussion in the High Court and Court of Appeal in Daniels highlights competing broad and narrow interpretations of the right. The different nature afforded to the right becomes clearer when assessed against that found in Phelps.

The two cases also present different paths taken to try to effect a remedy. This raises several questions in turn - is the right to education one that Parliament envisaged as being enforceable? If so, judicial review appears the obvious avenue for an area dependent on much executive discretion. However, following Daniels, the right to education may be so narrow as to allow room for effective judicial review only in the rarest of circumstances. If a remedy is available in private law, as in Phelps, then it may be questioned whether this could conceivably be termed "enforcement". Circumstances fulfilling the strict tests of negligence would be those where the right to education clearly was not fulfilled, a last resort situation. Damages then are compensation for the right not having been effective in the first place; enforcement of the right would envisage intervention before such damage occurred.

This article begins by outlining the dispute in Daniels. It describes the SE2000 policy and the general nature of the right to education, before noting the different outcomes the High Court and Court of Appeal found as to the content of the right. In the High Court Baragwanath $\mathrm{J}$ found that a substantive right existed. Perhaps reacting to this and with the Court's role in judicial review proceedings in mind, the Court of Appeal gave a more restricted reading of the right. A discussion of the right to education as outlined in Phelps highlights the distance between the two judgments on this point.

The Court of Appeal's narrow reading of the right raises questions as to whether judicial review is an appropriate avenue to use for enforcement. With that in mind this article then examines whether enforcement should be available through the legal system at all. This question will be addressed on both a theoretical and practical basis. It will first be considered whether the Court of Appeal saw the right to education as one that could be judicially enforced. The judicial review context of the case may have prompted the Court to take a narrow approach, so as not to be seen as substantially reviewing the policy. Secondly, the practical effect of the SE2000 policy means funding and discretion are apportioned on both a central and devolved level. This carries with it implications for the court's ability to give effect to the right to education. Possibly this is an area best ruled by the political process, with courts effectively able to step in only when there is such a departure from the right to education as to found a claim in negligence. Finally the extent of an enforceable right to education in New Zealand will be discussed.

10 Phelps v Hillingdon London Borough Council [2000] 4 All ER 504 (HL) ["Phelps"]. 
This article acknowledges that there is still a narrow scope for judicial enforcement of the right. Without a broader scope, however, the social costs of cases falling outside it potentially loom large. Thus broad enforcement is considered to be the more satisfactory route.

\section{THE DISPUTE IN DANIELS V ATTORNEY-GENERAL}

The plaintiffs in Daniels were a group of parents who felt their childrens' education had suffered as a result of the implementation of SE2000. Of particular concern was the Minister of Education's 1998 decision to disestablish special facilities and instead aim to meet the requirements of special needs students within a conventional school setting. Special units had been integral to the provision of special education under the arrangements prior to SE2000. The plaintiffs claimed their childrens' needs were not catered for adequately under the new policy. They contended that the policy was inconsistent with the Education Act 1989, and that the Crown had infringed section 98 of the Education Act 1964 through the closure of special units. Their rights under sections 3 and 8 of the Education Act 1989 had therefore also been infringed. Additionally, they argued that the Crown action was discriminatory and thus breached section 19 of the New Zealand Bill of Rights Act 1990 and section 21(h) of the Human Rights Act $1993 .{ }^{11}$

Both the High Court and the Court of Appeal noted that education in New Zealand was provided based on section 3 of the Education Act 1989. Section 3 states:

[E]very person who is not a foreign student is entitled to free enrolment and free education at any state school during the period beginning on the person's $5^{\text {th }}$ birthday and ending on the $1^{\text {st }}$ day of January after the person's $19^{\text {th }}$ birthday.

This provision relates to all school students. Parliament had, however, turned its mind directly to those with special educational needs in section 8 , which states:

Except as provided in this Part of this Act, people who have special educational needs (whether because of disability or otherwise) have the same rights to enrol and receive education at state schools as people who do not.

This was qualified by section 9:

(1) If satisfied that a person under 21 should have special education, the Secretary shall

(a) Agree with the person's parents that the person should be enrolled, or direct them to enrol the person, at a particular state school, special class or special clinic; or

(b) Agree with the person's parents that the person should have, or direct them to ensure that the person has education or help from a special service...

11 Daniels, above n 9, 3, 17 Baragwanath J. 
(4) No person shall be or continue to be enrolled at a special school, special class, or special clinic, or continue to have education or help from a special service, except pursuant to an agreement or direction under subsection(1) of this section.

Thus children with special needs have the same right to education as other children. However, in enacting section 9 Parliament had realised that those rights might be hollow if such students were simply treated the same as others. Section 9 thus provided a meaningful mechanism for ensuring that the sections 3 and 8 rights could be fulfilled. ${ }^{12}$ Given that the Education Act 1989 explicitly guaranteed special needs students the right to education, discussion in both courts focussed on the content and enforceability of the right.

The plaintiffs in Daniels were particularly concerned at the decision by the Minister to disestablish special facilities. The power to do so is located in section 98(2) of the Education Act 1964, which states:

The Minister may disestablish any special school, class, clinic, or service established under subsection (1) of this section, if he is dissatisfied with the manner in which the school, class, clinic or service is being conducted, or if he considers that sufficient provision is made by another similarly established special school, class, clinic, or service, or by any other school or class in or reasonably near to the same locality:

Provided that in the last-mentioned case he shall, if the controlling authority of the school, class, clinic, or service so requires, give 3 months notice of his intention to disestablish the same.

Judicial review was granted to the plaintiffs in both courts on the grounds that this provision had been breached. The decision to disestablish all special units was therefore ultra vires. However, the considerations the section required the Minister to have depended on the interpretation of the right to education. In the High Court this was read as a substantive right, ${ }^{13}$ whilst in the Court of Appeal it was interpreted to be procedural only. ${ }^{14}$ Each court, having interpreted the right differently, required different considerations from the Minister.

\section{A Special Education Policy in New Zealand}

"No area of education policy is as challenging or as fraught with as much difficulty as special education". ${ }^{15}$ In line with this statement, SE2000 was the first time a cohesive special education

12 Daniels, above n 9, 21-25 Baragwanath J.

13 Daniels, above n 9, 26 Baragwanath J.

14 Daniels, above n 9, 766-767 Judgment of the Court.

15 Nick Smith, Minister of Education (Speech to Secondary Principals' Association of New Zealand, 24 March 1999) in David Mitchell "Policies and Systems for Students with Special Education Needs" in Deborah Fraser, Roger Moltzen and Ken Ryba (eds) Learners with Special Needs in Aotearoa/New Zealand (2ed, Dunmore Press, Palmerston North, 2000) 29. 
policy had been formulated. Prior to this special education had developed generally as demand required. Over 300 special units attached to conventional schools had become the general setting for special education in New Zealand.

The 1980s reformulation of education policy known as "Tomorrow's Schools" resulted in the Education Act 1989. This policy developed the Special Education Discretionary Funding (SEDA), for which special needs students in conventional schools could apply.

As the name suggests, this funding was discretionary and depended simply on applications being made. No clear-cut criteria existed as to whether or not, or how much, funding a particular student would receive. The Special Education Service was contracted to provide special services as required. The system provided excellent support to a small number of students, but was run on an ad hoc basis with fairly low-level financial support coming from the government. In terms of "Tomorrow's Schools" this situation was not ideal as it required central involvement at the Ministry level. One of the tenets of the reforms was to devolve decision-making to individual school boards of trustees, where it was believed the best decisions for the particular school within the community could be made. SE2000 was seen as completing the reforms initiated by the Tomorrow's Schools policy. ${ }^{16}$

The Government's stated aim of SE2000 was "to achieve, over the next decade, a world class inclusive education system that provides learning opportunities of equal quality to all students."17 The SE2000 policy has two major components with the aim of helping schools to meet students' needs. These are: 18

- Information, education and specialist advisory support to assist families, schools and teachers achieve the best possible learning environment for all students with special education needs.

- A significant increase in funding and a modified system of resourcing to provide the necessary learning support for all students with high needs and to provide extra resources for schools to meet the needs of other students who require additional learning support.

The modified system of resourcing involves a degree of classification of special needs students into three high needs categories: Ongoing and Reviewable Resourcing Scheme (ORRS), Severe Behaviour Initiative (SBI), and Severe Language Initiative (SLI). Funding for these is provided on a devolved basis, with schools choosing a "fundholder" to manage resources for the student. A

16 C Brown and R Wills "Special Education 2000 - Getting it Right Together?" (Paper presented to the International Special Education Congress 2000: Including the Excluded, Manchester, 27 July 2000) 4.

17 Ministry of Education, above n 8, 5.

18 Ministry of Education, above n 8, 6. 
bulk-funded Special Education Grant (SEG) is given annually to all schools to provide for special needs assistance for students falling outside these categories.

In 2000 the government commissioned Dr Cathy Wylie to report on the implementation of SE2000. The Wylie Report raised a number of concerns.

\section{Ongoing and reviewable resourcing scheme (ORRS)}

This scheme aimed to provide guaranteed funding for those students with ongoing high or very high needs. It targets $1 \%$ of the school population, or approximately 7,100 students. ${ }^{19}$ "High or very high needs" are defined narrowly, and refer to those who will require ongoing and "intensive support to assist their learning or to meet their personal assistance needs at school."20 The strict requirements are designed to limit the number of students who will receive ORRS funding. There are guaranteed levels of funding and staffing entitlements for ORRS-funded students of up to a 0.2 full-time teacher equivalent credit and $\$ 12,500 .^{21}$ Following the Wylie Report, however, the definition of "high or very high needs" has been widened slightly to include some students with more moderate needs.

\section{Severe behaviour initiative (SBI)}

SBI funding is designed to manage the education of students manifesting behaviour that is: ${ }^{22}$

of such intensity, frequency, duration and severity that it jeopardises or threatens the physical safety of the student or others; severely limits the student's access to ordinary settings; and interferes with the student's social acceptance, sense of personal well-being and educational performance.

There are two responses available under this initiative. First, Resource Teachers: Learning and Behaviour (RTLBs), established to support schools and teachers in planning for and responding to students' educational needs, work to assist teachers and school boards of trustees to better manage severe behavioural problems. Secondly, Behaviour Support Teams (BSTs) comprised of specialists in behaviour management aim to reduce the incidence of disruptive and severely challenging behaviour in schools. ${ }^{23}$

19 Dr Cathy Wylie Picking Up the Pieces: Review of Special Education 2000 He Tätaritanga Mö te Mätauranga Motuhake 2000 <http://www.executive.govt.nz/minister/dalziel/wylie_review.doc> (last accessed 1 September 2004) 46.

20 Mitchell, above n 15, 36.

21 Mitchell, above n 15, 36-37.

22 Mitchell, above n 15, 37-38.

23 Mitchell, above n 15, 38. 


\section{Severe language initiative (SLI)}

This initiative aims to provide intensive support to students with severe communication needs. It has two components. First, a national training programme for teachers aims to better manage students with communication delays and disorders, especially in low-decile schools. ${ }^{24}$ Secondly, speech-language therapists will work both in the classroom alongside those with severe speechlanguage delays, as well as within speech-language clinics. ${ }^{25}$

\section{Special education grant (SEG)}

The SEG is an annually bulk-funded grant given to each school based upon a formula derived from the school's decile ranking and roll numbers. It is designed to aid those students who need support, aside from those with clearly identifiable high needs. ${ }^{26}$ Use of the SEG is left entirely to a school's discretion. The Ministry of Education encourages schools to use it to develop policies for providing for special needs students, and to develop creative responses to students' needs. ${ }^{27}$ However there are concerns as to how schools can be made accountable for use of the funding. ${ }^{28}$

There is also concern with the formula-driven nature of the funding. It is argued that some schools are "magnet" schools for those with special needs, as they have consistently cultivated a caring and supportive environment for those with special needs. ${ }^{29}$ Such schools are likely to attract more special needs students than other schools. Conversely other schools may have persistently "discouraged" special needs students from enrolling and thus may have very few or no special needs students at all. Both schools, however, will receive funding of the same weight (according to the SEG formula) to be able to provide for their special needs students. ${ }^{30}$ The SE2000 policy is designed to allow special needs students to receive education at any state school, but does not presently take account of the reality that there is an uneven distribution of special needs students. ${ }^{31}$

24 Schools ranked on a scale of 1-10 on the basis of the socio-economic status of the community from which children on their role are drawn. Schools with a decile 10 ranking are those with a high socio-economic (wealthy) community. Schools with a decile 1 ranking are in very poor areas.

25 Mitchell, above n 15, 38-39.

26 Ministry of Education, above n 8, 8.

27 Ministry of Education Managing the Special Education Grant: A Handbook for Schools (Ministry of Education, Wellington, 1998) 8-10, 14-15.

28 Wylie, above n 19, 15.

29 Wylie, above n 19, 8.

30 Mitchell, above n 15, 39-40.

31 Wylie, above n 19, 32, 52. 


\section{B Potential Issues with Special Education 2000}

The SE2000 policy has seen a huge increase in funding for special needs students, with a much larger number of students being reached. ${ }^{32}$ However, there remain concerns with the working of the policy. The potential issues with SE2000 are two-fold and relate to students both in the "categories" and those who are reliant on SEG funding to receive support for their special needs.

The overwhelming issue with the high needs categories is that the narrow criteria mean that many students are not included within them. Both the school and the parents of a child with special educational needs must provide extensive written applications for ORRS. Any assessments of the child made in support of the application are paid for by the parents. The Wylie Report noted that just under half of the current applications succeed. Particularly worrying was the fact that the number of applications that failed from low-decile schools, and from Maori and Pacific Island students, was disproportionately high. This supported an observation that the success of the application was perhaps based more on an assessment of the written application, than on an examination of a child's needs. ${ }^{33}$

Another concern with the high needs categories is that the criteria to receive funding are excluding deserving students. Anomalous results have appeared - there are examples of two students with similar conditions applying, but only one receiving funding. ${ }^{34}$ Reasons for a declined application are not given unless requested in writing by a parent. This is of particular concern as behaviour may be taken into account in assessing ORRS applications. The Children and Youth in Aotearoa Report to the United Nations documented this anomaly: ${ }^{35}$

In one case a student with an intellectual disability who behaved in a compliant manner in class, was declined funding because the student's behaviour did not match the funding criteria. By contrast a student who is intellectually disabled but behaves in a violent manner is likely to obtain funding.

Undoubtedly the violent behaviour is an extra factor that will need to be managed as part of the child's education. However parents and teachers may feel that better-behaved children are missing out as a result.

32 Daniels, above n 9, 22 Baragwanath J.

33 Wylie, above n 19, 41.

34 Wylie, above n 19, 43.

35 Appendix 15 "The Education of Children and Young People" in Action for Children and Youth Aotearoa Children and Youth in Aotearoa 2003: The Second Non-Governmental Organisations' Report from Aotearoa/New Zealand to the United Nations Committee on the Rights of the Child (Wellington, 2003) <http://www.acya.org.nz/Portals/0/ChildrenYouthAotearoa2003_FullReport.pdf> (last accessed 1 September 2004) 14. 
This highlights another issue: that the categories are inflexible and do not allow any cross-over. Thus the badly behaved intellectually disabled child will be fully funded under ORRS, rather than receiving funding from SBI. The inflexibility may cause schools to deliberately treat students differently in order to comply better with funding criteria. The Children and Youth in Aotearoa Report documents a case where a school that "sought support for two students with difficult behaviour was turned down because the students' behaviour was not bad enough. These same pupils were provided with assistance immediately following their suspension from school." ${ }^{36}$ Inflexibility of criteria causes huge anxiety, particularly for families who have been through the "traumatic" application process several times and have been turned down. ${ }^{37}$

A further point of concern is the support provided to students with moderate special needs. Many of these students previously had section 9 agreements but under SE2000 are expected to receive support from the SEG. This can be problematic. If a school has ORRS students whose support requires funding greater than the level they directly receive, this must come from the SEG, and can work to the detriment of moderate needs students. Similarly those "magnet" schools, as noted above, will have more special needs students, and so the funding available to all of them is spread thin. The 1998 decision by the Minister to disestablish all special units had particularly devastating effects for many moderate needs students who had been particularly supported within them. The Wylie Report noted that the closure of units bringing about a "loss of support and opportunity for these moderate needs students was a marked theme in the consultation." 38 These concerns prompted a group of parents to seek judicial review of the SE2000 policy in 2001.

\section{The Nature of the Right to Education}

There is extensive debate as to the nature of rights, ${ }^{39}$ which generally beyond the scope of this article. A brief discussion of the nature of the right to education is required, however, to place the courts' discussions of the content and enforceability of the right into context. There is debate whether education is an economic, social or cultural right, ${ }^{40}$ of which it indeed has elements. ${ }^{41}$

36 Appendix 15, above n 35, 14.

37 Wylie, above n 19, 42-43.

38 Wylie, above n 19, 8.

39 See generally Ronald Dworkin Taking Rights Seriously (Harvard University Press, Cambridge (Mass) 1977). Dworkin views legal protection of rights as a necessary precondition for the pursuit of individual goals within society. For a different view see Peter Gabel and Duncan Kennedy "Roll Over Beethoven" (1984) 36 Stan L Rev 1. Gabel and Kennedy discuss rights as having nothing to do with social reality, rather operating to alienate individuals from their social and political environment. In this respect formal rights are not seen as producing substantial justice.

40 See generally Louis Henkin The Age of Rights (Columbia University Press, New York, 1990) 1-5 for a brief discussion of the identifying features of economic, social and cultural rights as opposed to civil and political rights. 
However, the "relationship between the individual and the state in respect of education also has a civil and political content."42 As already noted, statements in international obligations illustrate the widespread acceptance of the right to education. ${ }^{43}$ With such support comes an equally widespread expectation that an education system will be provided.

Three observations then follow. First, the right to education entails a positive obligation on the State to provide a system of education. This mirrors international obligations, although such a system was in place in New Zealand long before such documents came into existence. ${ }^{44}$ The provision of a special education policy is in itself an acknowledgment by the State that such a responsibility lies with it; it is inconceivable that the provision of special education would be arbitrarily withdrawn. ${ }^{45}$ In the High Court in Daniels Baragwanath J enunciated the positive duty on the State by distinguishing the case from $R v$ Inner London Educational Authority ${ }^{46}$ and $R v$ Gloucestershire County Council, ex parte Barry. ${ }^{47}$ In both cases "duties" imposed by Parliament were to guide decision-making, but plaintiffs who would benefit if such duties were performed were denied a right to sue for enforcement. In the Education Act 1989, however, Parliament had gone further than simply imposing duties, and had imposed "rights" and "entitlements". These would only be meaningful if duties on the State were also imposed. ${ }^{48}$

Secondly, the widespread acceptance of the right means that its existence is not dependent on the explicit words used in statutes to describe it. Thus the right and the responsibilities following it can be found, even where negative language is used. This has been seen in the interpretation of the European Convention of Human Right's statement on education. Article 2 of the First Protocol to the Convention states:

41 See Department of Justice "A Bill of Rights for New Zealand: A White Paper" [1984-85] AJHR IA6, 112, para 10.179 where a distinction was made between civil and political rights, being generally negative rights imposing duties on the State to refrain from infringing them, as opposed to economic, social and cultural rights, which impose positive duties on the State to do something. This is a principal reason why the New Zealand Bill of Rights Act 1990 does not contain economic, social and cultural rights.

42 Anthony Bradley "Scope for Review: The Convention Right to Education and The Human Rights Act 1998" (1999) EHRLR 395, 396.

43 Education has been acknowledged in international human rights instruments as both an economic, social and cultural right, and as a civil and political right. See also Lord Lester of Herne Hill QC and David Pannick QC (eds) Human Rights Law and Practice (Butterworths, London, 1999) 255-256.

44 Education Act 1877.

45 See Education Act 1989, s 65E which places a high threshold for the withdrawal of any education.

$46 \quad$ R v Inner London Education Authority [1992] Admin LR 822.

$47 \quad$ R v Gloucestershire County Council, ex parte Barry [1997] AC 584.

48 Daniels, above n 9, 36 Baragwanath J. 
No person shall be denied the right to education. In the exercise of any functions which it assumes in relation to education and to teaching, the State shall respect the right of parents to ensure such education and teaching in conformity with their own religious and philosophical convictions.

Case law on this Article has generally focussed on the second limb, encapsulating the parents' rights. ${ }^{49}$ However the European Court of Human Rights has clearly articulated that "despite the negative formulation...Article 2 was considered to enshrine a right to education." 50 Thus the Court was able to consider and affirm the State's obligations to provide education despite the statutory language.

Following on from this, where the right is put explicitly and in positive terms, it becomes even clearer that courts may examine the responsibilities of the State to provide education. Baragwanath J commented in Daniels that "'rights' is a terms commonly used to denote that which the courts will enforce." 51 He went on to note that "it is the Court's duty to determine and express such entitlement and rights... Here there is no question of adjudication inconsistent with the expressed will of Parliament."52 The Court of Appeal also recognised the court's role, stating that "schools have duties correlative to the students' statutory rights and those general rights are capable of legal enforcement." 53 The differences in approach in each Court were not conflicts over the existence of the right, but of its content and enforceability. The Court of Appeal's narrow view of the content and enforceability potentially leaves some deserving cases without a direct path for enforcement. The wider approach taken by Baragwanath $\mathrm{J}$ in the High Court is therefore preferred.

\section{DANIELS V ATTORNEY-GENERAL: THE DIFFERENT CONSIDERATIONS IN THE HIGH COURT AND COURT OF APPEAL}

In the High Court, Baragwanath $\mathrm{J}$ found that there was a justiciable right to education to the extent that such education must be suitable, regular and systematic. These minimum standards coloured the considerations the Minister had to make when deciding to disestablish the special units. The Crown appealed Baragwanath J's ruling, posing three questions: ${ }^{54}$

(1) Is there any difference, and if so what, between the expressions "special educational needs" in s8 and "special education" in ss9 and 10 of the 1989 Act and in ss98-100 of the 1964 Act? What

49 Belgian Linguistic Case (No. 2) (1968) 1 EHRR 252; Kjelsden, Busk Madsen and Pedersen $v$ Denmark (1976) 1 EHRR 711; Campbell and Cosans v UK (1980) 4 EHRR 293; Valsamis v Greece (1996) 2 EHRR 294.

50 Bradley, above n 42, 399.

51 Daniels, above n 9, 35 Baragwanath J.

52 Daniels, above n 9, 14 Baragwanath J.

53 Daniels, above n 9, 766 Judgment of the Court.

54 Daniels, above n 9, 747-748 Judgment of the Court. 
educational facilities come within "special education" for the purposes of ss9 and 10 of the 1989 Act? Has the introduction of SE2000 breached these provisions?

(2) What is the nature of the "equal" or "same" right, under s8, of children with "special educational needs" to enrol and to receive education as children who do not have those needs? Has that right been breached?

(3) Did the Minister comply with s98(2) of the 1964 Act when he made the decision in 1998 to disestablish all special facilities, except the special schools?

In all of these areas the Court of Appeal adopted a much narrower approach than that taken by the High Court.

\section{A Question One}

This question required a comparison of the different definitions encompassed within the Education Acts of 1964 and 1989. The 1964 Act defines special education as: ${ }^{55}$

Education for children who, because of physical or mental handicap or of some educational difficulty, require educational treatment beyond that normally obtained in an ordinary class in a school providing primary, secondary, or continuing education.

This definition highlights the special needs of the student, and stresses that because of that, education beyond that normally obtained in an ordinary class is required. It perhaps also points to the extensive nature of special education; it is beyond that generally available in an ordinary class. This emphasises that there is a substantive element to special education. In contrast, the 1989 Act, in sections 2 and 9, expresses special education in terms of special facilities as defined in the 1964 Act. Thus "special education" is limited to "the specific institutions and facilities established or authorised by the Minister under section 98 of the 1964 Act, and to nothing else. It does not have the broader emphasis of the 1964 definition."56 In the 1989 Act it is expressed narrowly and in terms of facilities only.

It is interesting that the Court of Appeal substantially addressed this issue; in the High Court Baragwanath J explained the difference away in two paragraphs. He agreed that the 1964 definition was markedly wider than the 1989 definition. The latter did "not extend to the education of special needs students within the ordinary system except to the extent that they require additional - 'special' - education or help." ${ }^{57}$ Extrapolating from this, all special needs students had the right to attend a conventional school to the extent that it could cater for their needs. If it could not, a section 9

55 Education Act 1964, s 2.

56 Daniels, above n 9, 758 Judgment of the Court.

57 Daniels, above n 9, 25 Baragwanath J. 
agreement would come into play to allow the use of special facilities. ${ }^{58}$ Baragwanath $\mathrm{J}$ had held that the new provisions of ORRS, SBI, SLI and RTLB would all fall within the section 9 definition of "special education" facilities. Either scenario was still accommodated by the 1989 definition.

The Court of Appeal did not however see all these initiatives as falling within the 1989 Act definition. They held that ORRS fell within the definition as "the predecessors to ORRS were so established under section 98."59 However, the other elements of SE2000 did not come within the definition as they are "provided through the decisions of school boards of trustees...on the basis of the additional funding provided under the relevant aspects of SE2000."60 Therefore the only section 9 agreements that the Minister had to make were with those students attending special schools and those falling within ORRS, this presumably being seen as a "special service". As this had been complied with, no breach of section 9 could be shown.

The decision by the Court of Appeal to place ORRS within the borders of section 9, but to leave out the other defined high needs categories is not entirely convincing. As noted above, the SBI and SLI programmes were also designed to target the 1 percent of high needs students in those areas; along with ORRS the 3 percent of students with the most challenging special needs were to be catered for. Funding through these initiatives is tagged to specific students, with individual programmes drawn up to target their individual needs. Many, but not all, students who held section 9 agreements were envisaged as falling into one of the three high needs categories. Those who did not transfer over into the categories would have to rely on SEG funding. If the court's reason for allowing ORRS within section 9 was based on the previous section 9 arrangements seemingly "fitting", then it appears an anomaly to not allow SBI and SLI under section 9 as well.

In contrast, the SEG is designed for another group of students, the 4-6 percent of students with "moderate" needs. This funding is bulk funded to schools to provide for students as a group as they perceive best, rather than individually tagged to particular students. ${ }^{61}$ As schools' boards of trustees really decide use of the SEG, the distinction between the various programmes, if one must be made, is here. As the use of RTLB teachers is also decided at this level, it is appropriate to see this aspect alongside SEG when analysing the various SE2000 provisions.

However, it still appears that the Court of Appeal took a narrow approach to categorising the SE2000 schemes. If the 1989 definition had been read as widely as the 1964 definition it is possible that all of SE2000 would be considered as special education under section 9. Having chosen to limit the definition to that in the 1989 Act, however, it was limiting special education only to those

58 Education Act 1989, s 9(4).

59 Daniels, above n 9, 760 Judgment of the Court.

60 Daniels, above n 9, 760 Judgment of the Court.

61 Mitchell, above n 15, 35. 
schemes set up under section 98 of the Education Act 1964. No SE2000 provisions, including ORRS, were set up under this section. If the court wished to have ORRS fall within the 1989 special education definition, as it rightly should, then the broader 1964 definition should have been allowed and used, even if the corollary was to fit all of the SE2000 provisions under section 9.

Given that the point was not really in issue in the High Court, it is interesting that the Court of Appeal strived to find the outcome it did. It must be asked what the Court of Appeal was aiming to achieve in holding as it did. The narrow take on the definition distanced the Secretary of Education (the public servant heading the Ministry) from special needs students in terms of section 9. Under section 9 individual arrangements for each individual student must be agreed with the Secretary. All ORRS students had previously held section 9 agreements, so the provisions could be met by default. This was not the case for the other SE2000 provisions. If the other provisions also fell within the 1989 definition, the Secretary would be required to individually assess each student. Two observations can be made on this. First, this would require extensive central involvement when the context of the policy within "Tomorrow's Schools" was to move towards devolution. Secondly it provided a scenario in which Baragwanath J's minimum standards could practically be assessed. Thus the narrow definition laid the foundations for the Court of Appeal to interpret a much narrower right to education than that which Baragwanath $\mathrm{J}$ had found.

\section{B Question Two}

What is the nature of the "equal" or "same" right, under s8, of children with "special educational needs" to enrol and to receive education as children who do not have those needs? Has that right been breached?

In the High Court Baragwanath $\mathrm{J}$ began his consideration of the right to education by confronting the Crown's submission that the right was not justiciable. It was submitted that there was "too large a component of policy as to what budgetary allocation should be made, as against other public policies with which it competes." ${ }^{62}$ However, the national system of education and the statutory language belied this. Section 8 gave special needs students not only the right to enrol but also to receive education. In assessing this, the substantive nature of the right had to be considered. Therefore "whilst it is the function of the Crown and not the Court to determine the content of that education, it is the Court's responsibility to ensure that the adequacy of the education does not fall below certain minimum levels." 63 He had emphasised at the outset of his judgment that "the role of the Court is limited to reviewing compliance with the law" and that "the Crown has the authority and the responsibility to determine what policies are to be preferred and to apply public resources to secure a principled and workable regime." ${ }^{64}$ However, given the wording of section 8 , a substantive

62 Daniels, above n 9, 34 Baragwanath J.

63 Daniels, above n 9, 25 Baragwanath J.

64 Daniels, above n 9, 4 Baragwanath J. 
evaluation of the education provided under SE2000 was required in order to determine if the law had been infringed.

Having established that special needs students had a substantive right to education, Baragwanath $\mathrm{J}$ then turned to examine what comprised that right. He considered it was not practical to give a precise definition of the right to special education as the variety of special needs was so wide. However, he considered that the statutory language had to be construed as requiring an evaluation of, and a response to the educational needs, of each student. He acknowledged the force of the Crown submission that denied the right of a particular student to a particular provision. However, it would be going much further to state that "because the system cannot be required to provide everything, therefore it cannot be required to provide anything." 65

Because it was not practical to give a precise definition of the right, Baragwanath J proposed some minimum standards. He read this to require an "individual focus on every special needs student to ensure that each receives an education that is not clearly unsuitable (and in that specific sense is 'suitable'), and is regular and systematic."66 These were justiciable issues that could be determined with the help of expert evidence. Thus the court could hold them as colouring the considerations that the Minister had to have when making a decision under section 98(2).

The Court of Appeal tackled this question by noting, as Baragwanath $\mathrm{J}$ had, that the right to free enrolment and education for all children had a long history in New Zealand. The Court said that special education had generally developed itself, with the 1964 Act codifying what was already there. This take on the history stressed that special education policy could develop independently of the statutory framework. This differed markedly from Baragwanath J's history which noted the ad hoc development of special education but emphasised the important role special units had to play. The Court of Appeal's approach means that special education was again distanced from Ministry involvement. This in turn had consequences for the considerations the Minister would have to make when disestablishing special facilities under section 98(2).

The Court of Appeal then examined Baragwanath J's finding that children with special educational needs have a substantive right to education that is suitable, regular and systematic. The Court of Appeal made three observations on this finding. First, Baragwanath J's conclusions, based as they are on section 3, apply to all children, not just to those with special needs. Secondly, the obligation he found for the State to evaluate and respond to the educational needs of individual students again must extend to all school students, not just those with special needs. Thirdly, the

65 Daniels, above n 9, 35 Baragwanath J.

66 Daniels, above n 9, 26 Baragwanath J. 
court felt Baragwanath $\mathrm{J}$ had seen the issue of justiciability in all or nothing terms. ${ }^{67}$ This was based on his statements that: ${ }^{6}$

[I]t by no means follows that because the system cannot be required to provide everything, therefore it cannot be required to provide anything...The Crown's submission that the Courts can have no role to examine legality in this sphere goes too far.

To classify such statements as being in "all or nothing" terms seems odd. The question of justiciability in a given area inherently has an "all or nothing" nature: either the court can examine the issue, or it cannot because of policy concerns. If an area is justiciable, the question then arises as to how far consideration can stretch. The realm of executive discretion is a difficult one; ${ }^{69}$ the more policy based a decision is, the less likely the court will feel able to question it. ${ }^{70}$ However the statutory framework surrounding the decision also colours the justiciability inquiry. Where a decision was to be made based on educational concerns alone, lack of resources could not influence the decision. ${ }^{71}$ Thus in approaching the matter Baragwanath $\mathrm{J}$ was not really talking in absolute terms. Deciding that the right to education was justiciable because of the statutory provisions, the question then became a matter of degree - to what extent could the court review the SE2000 policy? Given that the case was of a general nature, as the Court of Appeal stressed, ${ }^{72}$ his conclusion can be seen as an outer limit: the right to education is justiciable to the extent that it is suitable, regular and systematic.

In investigating the "equal" right to education of those with special needs, the Court of Appeal began by considering the systems created by and under the Education Acts to promote education generally. These include statements of national educational goals, guidelines and policy and curriculum statements that must be included in each school's charter under section 60A of the 1989 Act. Under section 87(3) the board of trustees must report annually on how the school is performing in reaching the stated aims of the charter. The Education Review Office also reviews the performance of schools. In relation to special education, the Minister has commissioned an

67 Daniels, above n 9, 761 Judgment of the Court.

68 Daniels, above n 9, 762 Judgment of the Court.

69 Philip A Joseph Constitutional and Adminstrative Law in New Zealand (2ed, Brookers, Wellington, 2001) 739.

70 See CREEDNZ Inc v Governor-General [1981] 1 NZLR 172, 198; $R v$ Chief Constable of Sussex, ex parte International Trader's Ferry Ltd [1999] 2 AC 418, 429-430 Lord Slynn; 443-444 Lord Hoffman.

$71 \quad R v$ East Sussex County Council, ex parte Tandy [1998] AC 714, 749.

72 Daniels, above n 9, 762 Judgment of the Court. 
independent review ${ }^{73}$ and a research project. ${ }^{74}$ The Court also noted avenues for external scrutiny such as the Ombudsman.

Although not explicitly stated, it seems the Court felt that these alternatives belied the need for much judicial scrutiny. This is in contrast to Baragwanath J's approach. In his view judicial scrutiny was essential, otherwise the right would be enforceable only through indirect means. ${ }^{75}$ There is a complete divergence of views here. The existence of the same facilities was used by the High Court to ensure judicial scrutiny, but by the Court of Appeal to deny the need for it. The Court did, however, recognise that in addition to all of these avenues there would still be room for legal proceedings where a school failed to comply with its obligations. They stated that "schools have duties correlative to the students' statutory rights and those general rights are capable of legal enforcement."76 Furthermore, such rights can include those "enforceable by a particular individual arising out of actions affecting that person alone."77 Acknowledging that such rights existed, the question then turned to the content of those rights.

The Court of Appeal's assessment of the content of the "equal" rights was based on Baragwanath J's own criterion of an education that is suitable, regular and systematic. It found that "suitability", in itself, was an uncertain premise that may prove difficult for judges. ${ }^{78}$ This criticism is not unfounded as the test is uncertain. However, uncertainty is inherent in many judicial tests, so on its own this distinction carries little weight. Also Baragwanath $\mathrm{J}$ framed it within the context of the particular circumstances of a particular child. Once viewed as such, suitability would be able to take on much more meaning.

The requirements that education be regular and systematic were met in the statute in any case, through the procedural requirements of minimum days and hours, teacher registration and curriculum. Therefore, whilst there are rights under the 1989 Act enforceable by the Court, the minimum substantive rights suggested by Baragwanath $\mathrm{J}$ could not stand. There was no general right to education enforceable by individual students. Rather such rights are "essentially those specifically established by and under the legislation which...do in themselves provide for regularity and system and are designed to ensure appropriate quality."79

73 Wylie, above n 19.

74 Massey University Research Team Special Education 2000: Monitoring and Evaluation of Policy (Ministry of Education, Wellington, 2002).

Daniels, above n 9, 37 Baragwanath J.

76 Daniels, above n 9, 766 Judgment of the Court.

77 Daniels, above n 9, 766 Judgment of the Court.

78 Daniels, above n 9, 766 Judgment of the Court.

79 Daniels, above n 9, 766-767 Judgment of the Court. 
This conclusion also seems unduly narrow. The Court saw Baragwanath J's minimum standards as being uncertain. They attempted to clarify the situation by restricting rights to procedural rights statutorily designed to provide suitable, regular and systematic education. However the categories may be too strict now, causing some scenarios to slip between the cracks. One of the Court's own examples illustrates this. The Court provides the hypothetical case of a child who brings "compelling evidence of a complete failure by the Secretary to consider information plainly bearing on the contention that...under s9 they 'should have special education'."80 The Secretary's consideration of the child's position clearly would be a matter pertaining to the suitability of the child's education. However, in undergoing this exercise, account would be taken of what provision there currently is and, if a section 9 agreement were to be made, what new provisions should be in place for the child. Thus the boundary between whether this decision is a procedural or substantive matter may become blurred. This is a fairly extreme example; it is unlikely a court would see this as a substantive decision and not hold the Secretary to consider the child. However it serves to show that the Court's attempt to give clarity to the situation may still leave significant room for debate.

The Court of Appeal rejected Baragwanath J's approach of deciding whether the right to education in particular circumstances was justiciable or not. However, as the above example also shows, the question of justiciability is one that is always going to creep in when determining special education claims. The essential question will always be whether or not the court has the jurisdiction to consider a case, or certain parts of it. Baragwanath J recognised this, noting that each case should be looked at on its own facts, with the help of expert evidence to guide the court. ${ }^{81}$ Debate over whether a case will fit within the Court of Appeal's categories also means that individual cases will have to be scrutinised. The number that will succeed will, however, undoubtedly be much smaller. For those parents and students who feel aggrieved at the changes in the provision of education, judicial review may present as a hollow remedy.

\section{Question Three}

Did the Minister comply with section 98(2) of the 1964 Act when he made the decision in 1998 to disestablish all special facilities, except the special schools?

Both Courts used their formulation of section 8 rights to colour the considerations the Minister had to make when disestablishing special facilities under section 98(2) of the Education Act 1964. This section states that the Minister must have regard to the provision of special education made within a specific area.

Baragwanath $\mathrm{J}$ held that section 8 afforded a right to special needs students to receive an education that is suitable, regular and systematic. Therefore, the Minister had to make the decision

80 Daniels, above n 9, 766 Judgment of the Court.

81 Daniels, above n 9, 37 Baragwanath J. 
with these substantive rights in mind. This consideration went much further than simply having regard to the presence of other schools in an area and assuming that such schools would be able to provide for special needs students with their SEG. Rather it compelled the Minister to be sure that every special needs student could receive a suitable, regular and systematic education at another school in the same locality. There was no evidence that the Minister had done this, substantively or otherwise. Therefore the decision breached section 98(2), and was ultra vires.

In the Court of Appeal's view this decision was simply a procedural matter, of which no evidence showed such considerations as having been made. The Court agreed with Baragwanath J that the section required a locality by locality assessment to be made by the Minister before the decision to disestablish was made. ${ }^{82}$ However the considerations differed from Baragwanath J's position that such assessment must include a substantive evaluation. Rather the Minister had to ask whether the statutory requirements of suitability, regularity and system were sufficient in schools of each locality to make sufficient "provision" for special needs students previously in special units. What this actually entails of the Minister is not clear. Given the low threshold of these criteria, noting other schools in the locality would likely have been sufficient. It is clear from the Minister's affidavit that an assumption was made that the SEG would provide support in all schools and that no locality by locality consideration had been made. ${ }^{83}$ The test the Court of Appeal was proposing focused much more on the locality as opposed to the sufficiency provisions.

\section{Distinguishing the Different Approaches: Phelps v Hillingdon London Borough Council}

In Daniels' case the Court of Appeal's approach to the question of an enforceable right to education differed markedly from that found in the High Court. Baragwanath J found a substantive right to education with minimum requirements, within the context of each particular student. The Court of Appeal's response was to characterise the right as procedural on narrow and statutory-based grounds. Interestingly, both Courts gained some measure of support for their stances from the House of Lords' decision in Phelps v Hillingdon London Borough Council. Although this was a negligence case, the special education context was relevant to Daniels. The finding of a duty of care depended to a large extent on a basic right to education on which it could rest.

Phelps $v$ Hillingdon London Borough Council was one of four appeals heard collectively by the House of Lords. In the case of Phelps there had been a trial and appeal already; the other three were appeals from strike-out applications. All four cases concerned students with special needs - three were concerned with dyslexic students, the fourth suffered from Duchenne Muscular Dystrophy. Phelps was the first time an education case had substantially succeeded in England. The other three appeals also succeeded in that the strike out applications were denied.

82 Daniels, above n 9, 774-775 Judgment of the Court.

83 Daniels, above n 9, 773 Judgment of the Court. 
The plaintiff Pamela Phelps had been seen by specialist teachers and educational psychologists throughout her schooling, none of whom recognised she was dyslexic. Despite being given extensive remedial teaching, she made virtually no progress in her education. Rather than investigate further into possible learning difficulties, assumptions were made that the cause lay in emotional troubles. After 12 years of schooling she was functionally illiterate and unable to obtain a job except for short periods. She alleged that the Hillingdon London Borough Council had: ${ }^{84}$

failed to identify her needs and to exercise reasonable care of her at all three schools in the detection, assessment, diagnosis and treatment of her learning difficulties and/or dyslexia...[and] failed to provide or arrange for the provision of reasonably appropriate tuition and treatment. Damages were claimed on the basis of past and future loss of earnings and the cost of tuition.

The trial judge found that the educational psychologists employed by Hillingdon owed Pamela a duty of care, because it was reasonably foreseeable that their recommendations and advice would be relied and acted upon. A breach of this duty was found because the Hillingdon educational psychologist assumed emotional problems to be the cause and did not use a suitable test that probably would have pointed to dyslexia. Garland J held that "[t]his was more than an error of judgment: it was a failure to exercise the degree of care and skill to be expected of an ordinarily competent member of her profession." ${ }^{85}$ Hillingdon, as the employer of the psychologist, was vicariously liable for her negligence. The trial judge awarded damages of roughly $£ 50,000$ calculated as general damages, damages for loss of future earnings, and damages for tuition fees.

In the Court of Appeal the critical issue was whether the educational psychologist had assumed or undertaken a personal responsibility to Pamela to take reasonable care to assess her educational potential and provide strategies to improve her position. ${ }^{86}$ In the education argument in $X$ (minors) $v$ Bedfordshire County Council ${ }^{87}$ Lord Browne-Wilkinson had earlier stressed that, while a local authority could not be directly liable, it could perhaps be vicariously so where an employee owed a duty to a particular student. Stuart-Smith LJ in Phelps thought however that the educational psychologist was simply one of a multi-disciplinary team made up of general and remedial teachers responding to a student's needs. In this situation the psychologist was doing no more than discharge her duty to her employers, and did not owe Pamela a duty of care. ${ }^{88}$

84 Phelps, above n 10, 510-511 (HL) Lord Slynn.

85 Phelps v Hillingdon London Borough Council [1997] 3 FCR 621, 624 (QB) Garland J.

86 Phelps v Hillingdon London Borough Council [1999] 1 WLR 500, 514 (CA) Stuart-Smith LJ.

87 X(minors) $v$ Bedfordshire County Council [1995] 2 AC 633, 762 (HL) Lord Brown-Wilkinson ["X(Minors)"].

88 Phelps, above n 86, 519 Stuart-Smith LJ. 
The House of Lords in Phelps approached the appeal by emphasising that in another earlier decision, Barrett $v$ Enfield London Borough Council, ${ }^{89}$ it had held that local authorities could be liable in negligence for damage resulting from acts done in performance of a statutory duty. A duty of care having been found, an element of statutory discretion would not of itself deny an allegedly negligent act being the basis for a cause of action, unless it involved a weighing of competing public interests, or if Parliament clearly intended that the issue be non-justiciable. The House of Lords then examined the question of whether a direct or vicarious duty was owed by the authority. Whilst not ruling out the possibility of direct liability, ${ }^{90}$ Lord Slynn felt it would only apply in unlikely scenarios, of which Pamela's case was not one. The appeal then turned on whether vicarious liability could be established.

In relation to vicarious liability Lord Slynn asked: ${ }^{91}$

Whether there is any overriding reason why

(a) that person should not owe a duty of care (the first question) and

(b) why, if the duty of care is broken by that person, the authority as employer or principal should not be vicariously liable (the second question).

In addressing the first question Lord Slynn emphasised the professional standard required in negligence, that "persons exercising a particular skill or profession may owe a duty of care in the performance to people who it can be foreseen will be injured if due skill and care are not exercised." 92 Because a higher standard was required there was no reason to grant a blanket immunity.

He then went on to address Stuart-Smith LJ's assessment that educational psychologists owed duties only to their employers, not to students they tested. He agreed that a duty was owed to the employer, but held that this did not mean that a correlative duty could not be owed to the child as well. This may not always be the case, particularly where the psychologist is simply making general observations. However: ${ }^{93}$

89 Barrett v Enfield London Borough Council [2001] 2 AC 550 (HL).

90 See also S v Attorney-General (15 July 2003) CA 43/02 paras 64-70 Blanchard, McGrath, Anderson and Glazebrook JJ, and Wv Attorney-General (15 July 2003) CA 227/02 para 34 Judgment of the Court, where the New Zealand Court of Appeal also considered the question of whether direct or vicarious liability would be appropriate in the context of negligent placements of children with abusive foster parents.

91 Phelps, above n 10, 517 Lord Slynn.

92 Phelps, above n 10, 517 Lord Slynn.

93 Phelps, above n 10, 518 Lord Slynn. 
Where an educational psychologist is specifically called in to advise in relation to the assessment and future provision for a specific child, and it is clear that the parents acting for the child and the teachers will follow that advice, prima facie a duty of care arises.

Thus in Pamela's case there was no reason why the psychologist should not owe a duty of care.

On the second question, Lord Slynn noted that, prima facie, education authorities will be vicariously liable for the negligence of their employees. This would only be negated if policy reasons dictated that those providing services would be hampered by vicarious liability. The higher professional duty, however, ought to take care of this as it will be harder to prove claims. Furthermore the professionalism of those providing educational services means that liability cases will be few and far between. Thus policy reasons did not stop the education authority from being vicariously liable.

On the question of breach and causation the House of Lords upheld the findings of the trial judge. More thorough testing should have initially been done; and tests should have been repeated when so little progress was made despite remedial teaching. As to causation, their Lordships agreed with the trial judge that, if teaching appropriate to her needs had been given, Pamela would be "somewhat, perhaps substantially, more literate than she is now",94 and would be able to be employed in work requiring literacy. Thus the elements of negligence had been fulfilled, and Hillingdon was vicariously liable. The House of Lords restored the damages awarded by the trial judge.

Phelps has engendered mixed feelings in the United Kingdom. Those who oppose making educational authorities liable cite the "floodgates" argument as a valid policy reason not to allow claims - that the courts will be inundated with students feeling their education was not as good as it could be. There was some evidence in Phelps that litigation in education had definitely increased after X(minors); ${ }^{95}$ Phelps was the first to succeed beyond strike-out stage. Other claims have progressed to trial, but have failed at the causation stage. ${ }^{96}$ It seems that education authorities can generally rely on the professional standard of their teachers as general protection against successful claims. ${ }^{97}$

Alongside the floodgates argument is that which states that if claims are allowed, precious resources will be diverted into insuring or defending against claims, rather than going into providing

94 Phelps, above n 10, 520 Lord Slynn.

95 Phelps, above n 86, 516-517 (CA) Stuart-Smith LJ. See $H$ v Isle of Wight Council (2001) WL 825780 QB.

97 Richard McManus QC "The House of Lords' Ruling in Phelps $v$ London Borough of Hillingdon and its Implications" (2000) 1 Edu LJ 200, 206. 
education. ${ }^{98}$ This also assumes, however, that strike-out applications will not be successful. Given that the three strike-out appeals heard together with Phelps all succeeded, this may appear so. However the Law Lords in Phelps were quick to reassure that this was not the case. Only genuine claims would be allowed to proceed to trial, and only those deserving claims would actually succeed. ${ }^{99}$

The corollary of this argument is that justice should be done, even if it comes at a price. ${ }^{100}$ This follows on from Lord Browne-Wilkinson's statement in $X$ (minors) that a rise in the costs of defending an education authority is the "price which might have to be paid in the interests of justice."101 It is also pointed out that the effect of such cases will be to improve the standard of education provision for all students. There is some evidence that this has been the case in Australia, where personal injury litigation against schools has lead to increased safety awareness. ${ }^{102}$ If this is so, several cases along the lines of Phelps may be a small price to pay for a conscious increase in standards.

One further observation on Phelps is that the case succeeded because of the time in which it was heard. The European Court of Human Rights' judgment in Osman $v$ United Kingdom ${ }^{103}$ had made the courts extremely wary of not allowing public authorities to be sued; following on from Barrett the courts felt bound to allow claims to go ahead. ${ }^{104}$ This is undoubtedly the case, but hardly an unusual feature of Phelps. Cases are always influenced by the setting in which they are heard. Two further comments can be made. First, the future success of education claims will depend on the conservative nature of the courts. If too many, seemingly undeserving cases are allowed to go to trial or succeed, the reaction will likely be to tightly control the option of litigation. Secondly, the law as it now stands is noted as being much more in line with the continental European situation in general. ${ }^{105}$ Whilst the United Kingdom will inevitably be influenced by Europe, the ability to sue in

98 Alastair Mullis "Case Commentary: Phelps $v$ Hillingdon London Borough Council A Rod for the HunchBacked Teacher?" (2001) 13 CFLQ 331, 338-339.

99 Phelps, above n 10, 530-531 (HL) Lord Nicholls.

100 Duncan Fairgrieve "A Tort Remedy for the Untaught? - Liability for Educational Malpractice in English Law" (2000) 12 CFLQ 31, 39.

101 X(minors), above n 87, 762 Lord Browne-Wilkinson.

102 Varnham, above n 6, 103.

103 Osman v United Kingdom (1999) 29 EHRR 245.

104 Alastair Mullis "Case Commentary: Barrett v Enfield London Borough Council A Compensation-Seeker's Charter?" (2000) 12 CFLQ 185, 191-192.

105 Mullis, above n 98, 337. 
the United Kingdom may depend on the domestic mood towards "encroachment" from Europe. ${ }^{106}$ Given that the decision is influenced by European concerns, however, it will be much harder for the United Kingdom courts now to effect a retreat. ${ }^{107}$

The most striking effect of Phelps is that the House of Lords held that there was a duty on education authorities to assess and respond to individual students' needs. This went so far as to raise a duty to provide appropriate remedial teaching; trial judge Garland $\mathrm{J}$ found the lack of review of Pamela's remedial teaching programme as an element of the breach of duty. Baragwanath $\mathrm{J}$ held that Phelps extended to a "failure to meet professional standards in discerning and catering for pupils' educational needs."108 This finding points towards his assessment that the right to education required an assessment of every special needs student, to ensure that suitable, regular and systematic provision was made.

The Court of Appeal in Daniels did not draw the same conclusions from Phelps. It was quick to deny that Phelps supported any substantive right to education. Rather, the Court distinguished it on several grounds. First, it concerned a "claim by an individual that rights owed to that particular person were breached." 109 This was in contrast with the group action brought in Daniels. It is questionable whether this distinction is valid. Whilst Daniels involved general considerations, in that no one plaintiff was claiming individual relief, the plaintiffs were essentially asking the Court to recognise that there was a substantive right to education. Such a finding would require the Minister to take into account the individual circumstances of each student. Thus Daniels was also indirectly concerned with claims by individuals that rights owed particularly to them had been breached.

Secondly, the Court of Appeal distinguished Phelps as succeeding in common law negligence rather than under statute. To further distinguish the context, the Court noted that in Phelps Lord Slynn had "held specifically that damages could not be sought for breach of statutory duty."110 With respect, this difference involved an overtly narrow reading of Lord Slynn's speech with regards

106 See Takis Tridimas The General Principles of EC Law (Oxford University Press, Oxford, 1999) 160-162. National courts may at times find it difficult to apply new principles coming from European jurisprudence. An example of this can be found in Malcolm Jarvis The Application of EC Law by National Courts: The Free Movement of Goods (Clarendon Press, Oxford, 1998) 195-200, 439-445. In the context of Sunday trading, the United Kingdom courts effectively refused to apply the proportionality test required by European jurisprudence, and instead replaced it with a test of reasonableness.

107 See Gordon Slynn Introducing a European Legal Order (Stevens \& Son Ltd/Sweet \& Maxwell Ltd, London, 1992). The supremacy of European law means the United Kingdom courts have a duty to override any rule of national law found to be in conflict with any directly enforceable rule of Community law. This position was recognised in the United Kingdom in Factortame and Others [1990] ECR I-2433.

108 Daniels, above n 9, 37 Baragwanath J.

109 Daniels, above n 9, 767 Judgment of the Court.

110 Daniels, above n 9, 768 Judgment of the Court. 
to the inability to claim damages for breach of statutory duty. Lord Slynn in fact highlighted the importance of effective remedies being available. He held that where a statutory duty was prescribed a civil action must be available in the absence of prescribed penalties, otherwise the duty would be nothing but a "pious aspiration". ${ }^{111}$ In the education context the nature of the national system of education and remedies available in judicial review indicated that Parliament did not intend to create a remedy of damages. To the extent that the statement quoted in the Court of Appeal appeared to belie the enforcement of Crown duties to provide an education system, it must be seen as out of context.

This holds little weight. Whilst different considerations are at stake, claiming in negligence presupposes that a duty of care is present. Whether a duty of care exists will be relevant to the existence of a right to education in the circumstances. Although a right to education is not a necessary prerequisite for a duty of care to arise, a substantive duty will inform any right to education that does exist. The finding of an extensive duty of care in Phelps, involving a response to an individual student's needs, would suggest a substantial right to education.

Following its consideration of Phelps the Court of Appeal held that it could not support the right to education as stipulated by Baragwanath J. ${ }^{112}$ The Court went on to hold that Phelps, and other cases cited by Baragwanath J, ${ }^{113}$ did not affect its "conclusion that there is no freestanding general right, held by each student under sections 3 and 8."114 In so doing, the Court effectively drew indirect support for its finding that the right was limited to statutorily defined procedures. Given that a claim of negligence in education had succeeded in the House of Lords, there had to be some basis on which a duty of care could lie. Phelps thus indirectly supported the finding that some strictly defined rights did exist.

\section{THE COURT OF APPEAL'S APPROACH IN DANIELS}

The Court of Appeal's approach in Daniels is much narrower on all aspects than that taken by Baragwanath $\mathrm{J}$ in the High Court. The Court restricted the definition of "special education" in the 1989 Act only to those special services set up under section 98 of the 1964 Act. This reduced the substantive approach that Baragwanath $\mathrm{J}$ had taken to the question of special education. The Court then denied the existence of any substantive right to education that is suitable, regular and systematic. Instead, only procedural rights under the Act falling within these areas could be seen as

111 Phelps, above n 10, 516 Lord Slynn. See also Cutler v Wandsworth Stadium Ltd [1949] 1 All ER 544, 548 (HL) Lord Simonds; Lornho Ltd v Shell Petroleum Co Ltd (No2) [1981] 2 All ER 456 (HL) Lord Diplock for further comments.

112 Daniels, above n 9, 770 Judgment of the Court.

113 Re S (Minors) (Care Order: Implementation of Care Plan) [2002] 2 AC 291; R v East Sussex County Council, above n 70; Sinnott v Minister for Education [2001] 2 IR 545 (SC).

114 Daniels, above n 9, 770 Judgment of the Court. 
enforceable rights to education. Finally, the Court did agree with Baragwanath $\mathrm{J}$ that the disestablishment of special services had breached section 98(2) of the 1964 Act. However, this was found purely on the lack of procedural evidence rather than a lack of substantive assessment of other facilities.

It must be asked why the Court took the approach it did. There are several possible answers to this. One factor may be that the Court was very aware of the judicial review context in which Daniels was heard. To this extent it did not want to convey any sign of reviewing government policy on its merits. This is further complicated by the devolved nature of the policy. If individual decisions are made or influenced at school level, is this really an executive action that the Court can look at? Alternatively it is possible that the Court viewed the right to education as best enforced through the political process. If this was the case then it was not appropriate for the Court to do any more than give minimum meaning to the statute.

\section{A The Judicial Review Context}

Judicial review is characterised by scrutiny of the form and procedure of an action as opposed to a substantive evaluation of it. This judicial self-restraint is "founded on the reluctance of the courts to encroach on the exercise of supremacy of Parliament, or to unduly restrict the acts of the Executive."115 The Court of Appeal's narrow approach shows a court extremely wary of appearing to interfere with government policy to any extent. It emphasised the consolidated policy and large increase in funding provided for special education. ${ }^{116}$ In the High Court Baragwanath $\mathrm{J}$ saw these as affecting an individual's right to education. It followed that substantive enquiries had to be made. The Court of Appeal viewed this, however, as policy couched in executive discretion, and as such afforded it a high level of deference.

The devolved nature of the policy complicated this matter even further. The policy allowed many decisions about the provision of special education to be made at school level. This may question whether such a decision really is an action of the executive and as such whether the Crown really is the appropriate defendant. School level decisions are however made within the statutory scheme, so there is still indirect Ministry involvement. This question has been in the judicial review background since the "Tomorrow's Schools" policy began devolution towards school level. This was particularly emphasised in Maddever $v$ The Umawera School Board of Trustees ${ }^{117}$ where Williams J said that: ${ }^{118}$

115 Charles Chauvel Historical Trends and Key Principles in Judicial Review $<$ http://www.conferenz.co.nz/2004/library/c/chauvel_charles.htm> (last accessed 1 September 2004).

116 Daniels, above n 9, 750-751 Judgment of the Court.

117 Maddever v The Umawera School Board of Trustees [1993] 2 NZLR 478 ["Maddever"].

118 Maddever, above n 117, 508, Williams J. 
[E]xcept in rare cases it would be wrong for the Court to intervene too readily in cases brought against Boards of Trustees in relation to purely managerial or administrative matters not seriously affecting the rights of students...[i]f such matters become contentious they should be negotiated, mediated and resolved at the local level.

To the extent that the Court did not really want to get involved, the Court of Appeal's narrow approach is consistent with this view.

However, the Court of Appeal has arguably been too narrow here. Whilst it is appropriate that boards of trustees' decisions should be addressed at the local level, the plaintiffs in Daniels had serious concerns about the education their children were receiving. The decision to mainstream affected the services available to them, striking at the very heart of the education provisions for them. In these circumstances the matter is clearly beyond a managerial level. If the provision of special education support could be termed an administrative matter, then it is still one clearly affecting the rights of students. In many ways the plaintiffs in Daniels presented a classic scenario for judicial review. To this extent the Court of Appeal's judgment should be read as conservative on this point.

In taking the narrow approach it did, the Court of Appeal was undoubtedly reacting to Baragwanath J's assessment of a substantive right. ${ }^{119}$ It must be questioned whether Baragwanath J went too far in his assessment, stepping into the realms of substantive review. There is some indication that Baragwanath $\mathrm{J}$ was aware that his judgment could be interpreted as such. He therefore tried to distinguish his approach by noting the House of Lords decision in Re S. ${ }^{120}$ Lord Nicholls in that case emphasised the undesirability of courts trespassing beyond their functions and departing from fundamental features in the Acts they were considering. ${ }^{121}$ Baragwanath $\mathrm{J}$ considered that here it was "the executive, not the judiciary, that had misapprehended the will of Parliament...there is no question of adjudication inconsistent with the expressed will of Parliament; the question is whether the executive has conformed with that expressed will."122 Thus he viewed the enquiry as procedural, but encompassing substantive considerations; the Court of Appeal's approach can be better characterised as procedural in every respect.

119 The Court was perhaps aware of policy arguments negating the creation of substantive rights to education in the context of negligence in American cases - see generally Peter $W v$ San Francisco Unified School District (1976) 60 Cal App 3d 814; Donohue v Copiague Union Free School District (1979) 418 NYS 2d 375; Hoffman $v$ Board of Education of the City of New York (1978) 410 NYS 2d 99. In particular the arguments focussed on other social and cultural factors which may also have contributed to a student's lack of effective learning.

$120 \operatorname{Re} S$, above n 113.

121 Re S, above n 113, 312-313 Lord Nicholls.

122 Daniels, above n 9, 44 Baragwanath J. 


\section{B Is Political Enforcement a more Appropriate Path?}

Underlying the Court of Appeal's approach in Daniels is perhaps an uneasiness as to whether the right to education is really a right the courts should be enforcing. Instead it may be that concerns surrounding the right would be better left to the political process to resolve. The House of Lords gave such a direction in O'Rourke v Camden London Borough Council. ${ }^{123}$ This was, like Phelps, a case in negligence where consideration of the issues had important consequences for the rights at stake: in this case, to adequate housing. Lord Hoffman, with whom all members of the Court agreed, held after examining the legislation and policy considerations, that no enforceable duty lay on the State. ${ }^{124}$ Mr O'Rourke would benefit from State action, but could not enforce it, although he could bring a judicial review claim if he had standing to do so. The House of Lords here was wary of giving substance to any rights, as the Court of Appeal were in Daniels.

However there are marked differences between the situation in O'Rourke and that in Daniels. First, as already traversed, there is an explicit right to education given in the Education Act 1989. Thus the plaintiffs were not asking for a right to be judicially created, rather just for one to be interpreted. Secondly the two cases are at different ends of the spectrum of relief sought. Daniels involved a group seeking judicial review in the context of an express right to education, $\mathrm{Mr}$ O'Rourke was an individual seeking damages when the statutory "right" to housing was not nearly so clear. The policy arguments against finding for Mr O'Rourke are far weightier than those against finding for the plaintiffs in Daniels.

There is further uneasiness with the notion of judicially enforcing rights with a significant social content. Based on American data Gerald Rosenberg has theorised that where social reform is the goal of litigation, it will only in very rare circumstances be successful due to the lack of ability of courts to enforce their own decisions. ${ }^{125}$ With this in mind, he advises that interest groups would be better off investing their energies in the political process to effect the desired change. ${ }^{126}$ The emphasis on interest groups is relevant to Daniels. The plaintiffs had essentially formed an interest group; no individual facts were pleaded. ${ }^{127}$ The lack of individual consequences arising out of the Minister's decision made it difficult for the Court to judicially review the decision. ${ }^{128}$ In this respect the Court's uneasiness can be well understood.

123 O'Rourke v Camden London Borough Council [1998] AC 188.

124 O'Rourke, above n 123, 196-197 Lord Hoffman.

125 Gerald N Rosenberg The Hollow Hope: Can Courts Bring about Social Change? (University of Chicago Press, Chicago, 1991).

126 Rosenberg, above n 125, 339-343.

127 Daniels, above n 9, 746-747 Judgment of the Court.

128 See Attorney-General v Refugee Council of New Zealand Inc. [2003] 2 NZLR 577, 592-594 Blanchard, Tipping and Anderson JJ, 611-612 McGrath J. The Refugee Council of New Zealand Inc brought 
Other aspects of Rosbenberg's theory do not fit so well within the Daniels context, however. The plaintiffs were not striving for social reform; the development of the SE2000 policy showed a clear commitment to provide for special educational needs in any case. Rather the plaintiffs simply wanted relief from a situation they saw as disadvantageous to the education of their children. With this in mind the advice to better invest energy in the political process to effect change loses its strength. The minority context of the plaintiffs, coupled with the already large increase in resources committed to the area, means that direct lobbying of Parliament may meet with little success.

The minority context is also likely to be fatal to any indirect success through the ballot box. If any political party actually devised an "action plan" to meet the plaintiff's concerns, the chances of voters swinging on the issue are likely to be almost non-existent. ${ }^{129}$ Recourse to international instruments such as the United Nations Convention on the Rights of the Child may strengthen political lobbying. However, courts have also been open to the use of international instruments to help decide cases. ${ }^{130}$ Going to court may therefore present a more direct option for giving meaning to international obligations. Rosenberg notes further that litigation tends to be more successful when accompanied by domestic favour on the issue. ${ }^{131}$ With this in mind, and given Baragwanath J's consideration that we are currently in a "rights" era, ${ }^{132}$ recourse to the courts seems the sensible option.

\section{AN ENFORCEABLE RIGHT TO EDUCATION IN NEW ZEALAND?}

The Court of Appeal's narrow formulation of the right to education seems to undermine the ability to enforce the right in a New Zealand court. However, the Court itself noted that there would still be some enforceable rights - those procedures related to regularity and system. In a small number of cases this might be available for parties seeking relief. For example, as noted above, a school suspended pupils in order to bring them within the criteria for SBI funding. Such students could perhaps claim that to be excluded from school purely to receive funding breached their procedural rights to a regular and systematic education (as long as the exclusion of SBI from the 1989 Act's definition did not itself exclude such claims). The enforceability of these rights may help

representative proceedings on behalf of persons detained in the Mangere accommodation centre while their applications for refugee status were determined under the Immigration Act 1987. The Court of Appeal found the general nature of the case made it difficult to rule, and would have preferred to be scrutinising the facts of individual cases.

129 Thomas Geuther "The Search for Principle - The Government's Liability in Negligence for the Careless Exercise of its Statutory Powers" (2000) 31 VUWLR 629, 650.

130 See for example Tavita v Minister of Immigration [1994] 2 NZLR 257, 266 (CA) Cooke P.

131 Rosenberg, above n 125, 31.

132 Daniels, above n 9, 35 Baragwanath J. 
those concerned with the funding criteria for the SE2000 provisions. However, it will only be of assistance in very limited circumstances.

There is also the possibility that, if the right were breached to the extent that the tests of negligence could be fulfilled, the courts would be willing to uphold a duty of care, and thus indirectly recognise a substantive right to education. The success of Phelps in the House of Lords points to the potential for similar success in the New Zealand courts. ${ }^{133}$ When the ability to sue the executive branch in New Zealand is considered, this potential seems quite real. Following AttorneyGeneral $v$ Prince and Gardner ${ }^{134}$ and the Privy Council decision in B and others $v$ AttorneyGeneral, ${ }^{135}$ there is no real restriction on the ability to sue the Government based on the traditional misfeasance/nonfeasance divide. The recent Court of Appeal decisions of $S v$ Attorney-General ${ }^{136}$ and $W v$ Attorney-General ${ }^{137}$ also raise the possibility of liability being found either on a direct or vicarious basis. Thus the devolved nature of the special education policy, which might be a difficult consideration for a judicial review court, may have far fewer problems in the context of tort liability.

Given some of the issues with the SE2000 policy, potential tort liability should be kept in mind. Concerns were earlier noted as to the seemingly arbitrary nature of decisions on ORRS funding. A child whose funding application was continually denied, and appropriate provision for whom was not made is not very far removed from the situation in Phelps. Similarly the lack of accountability that schools face as to the use of their SEG funding could likewise lead to such claims. A school that outfitted a new technology suite at the expense of their special needs students may well be considered negligent if those students suffered damage as a result. There would be scope for judicial review in this situation, for example if the relevant consideration of special needs students was not made. However, if the decision was procedurally sound, it may be difficult for such students to show that it had infringed their procedural right to a regular and systematic education. In such a situation torts claims may appear the only option in terms of judicial enforcement. The position of those schools that deliberately discourage special needs students could well be caught as well, if an individual student was able to again show that they had suffered as a result of being effectively excluded.

133 See Grant, Woolley, Staines and Grant v Victoria University of Wellington [2003] NZAR 185. In what was essentially a claim of dissatisfaction as to the quality of a Masters degree course, Ellis $\mathrm{J}$ rejected policy arguments drawn from the American education "malpractice" cases and refused to strike out the case. The case was later settled out of Court.

134 Attorney-General v Prince and Gardner [1998] 1 NZLR 262.

135 B and Others v Attorney-General (16 July 2003) Privy Council PC 1/2003.

$136 S$ v Attorney-General, above n 90.

137 W v Attorney-General, above n 90. 
The consequence of considering these potential actions is to show that there is still a substantial right to education, however one that is virtually unenforceable. This is not an ideal situation - given that there is an explicit statutory right, there ought to be an efficient enforcement mechanism. Indirect mechanisms such as recourse to the Ombudsman or Commissioner for Children may be of assistance. ${ }^{138}$ Their powers are limited, however, and such assistance may not be able to effectively remedy a situation - a direct approach is thus also desirable. ${ }^{139}$ Ideally judicial review would be able to act as such a mechanism: such intervention would occur much earlier than tort litigation, and thus be more efficient. It is also questionable whether tort liability could be seen to be "enforcement" of the right to education. By the time the strict negligence tests are able to be fulfilled, serious damage, with consequential social costs, ${ }^{140}$ may have already been suffered. In comparison, judicial review can be seen as an effective enforcement measure as the courts are able to step in and protect a plaintiff's right to education before the circumstances get any worse. As in many other areas of life, early intervention would be a strength here.

\section{CONCLUSION}

The famous educationalist Dr Beeby is reported to have once said that "there is always some tension between the controllers and the consumers of education and, in the long run, the consumers' purposes usually prevail."141 It can well be imagined that attempts to enforce the right to education would be within the consumers' purposes; this article has illustrated however that such purposes will not necessarily prevail in the New Zealand courtroom under the law as it presently stands. The Court of Appeal's decision in Daniels has left judicial review as an all but hollow remedy in terms of enforcing the right to education in New Zealand. Only exceptional cases will fall within the Court of Appeal's narrowly defined right to education. Conversely, and somewhat ironically, if the

138 See Daniels, above n 9, 762 Judgment of the Court; Phelps, above n 10, 535 Lord Clyde. Lord Clyde still however emphasised the need for a direct enforcement route. On this point it is interesting to note that a Special Educational Needs Tribunal was set up in 1994 in the United Kingdom to directly deal with disputes in special education without the absolute need to go to court. For more information see generally Neville Harris "Special Educational Needs - The Role of the Courts" (2002) 14 CFLQ 137.

139 The existence of such cheaper and quicker indirect mechanisms means it is likely recourse to the courts would probably be used sparingly. This in itself bolsters the argument to provide such recourse opportunities in that it will only be used by those who genuinely believe their rights are in need of the court's protection.

140 See $S$ v Attorney-General, above n 90, para 58 Blanchard, McGrath, Anderson and Glazebrook JJ. In the context of negligent placements of children with foster parents by whom they were sexually abused, the Court of Appeal was open to arguments of high social costs involved when tests for negligence were fulfilled.

141 R Baker "A challenge for Educational Transformation: Achieving the Aim of 'Thinking and Acting Locally, Nationally and Globally' in a Devolved Education System" (Paper presented to the International Forum on Education Reforms in the Asia-Pacific Region: Globalisation, Localisation and Individualisation for the Future, Hong Kong, 16 February 2001). 
right were breached to such an extent that a claim sounded in negligence, the prospect of courtroom success would be quite conceivable.

This conclusion seems out of step both with New Zealand's long history of providing State education, and with the desire to create a world-class inclusive special education system. ${ }^{142}$ There currently is a gap between the right to education and the ability to enforce it, lack of which may belie the effective nature of the right itself. In terms of special education, the effects flowing on from this lacuna potentially carry huge social costs. The experience of the plaintiff in Phelps, who was effectively unable to manage any employment requiring literacy, is testament to the extensive social costs that are possible if there is no effective path to a remedy. The Court of Appeal has recently accepted arguments as to the heavy social costs that potentially follow foster child placements where abuse occurs. ${ }^{143}$ It is anomalous that this was not also recognised in the special education context. If the special education system is failing a distinct group that it sets out to benefit, the lack of recourse to early and effective judicial intervention is concerning. Given its minority context, this is not a scenario that the "ballot box" can readily be expected to remedy. ${ }^{144}$ Beyond other indirect mechanisms effective judicial review could potentially protect and enforce a special needs student's right to education with much more force than reliance on the political system.

This article examined the nature of the right to education and the ability to enforce it within the context of special education in New Zealand. Working from the basis that the right to education incorporated a positive obligation on the State to provide education, a discussion of Daniels highlighted the possible interpretations of the content of the right. It found the High Court and Court of Appeal to have divergent views; a substantive right to education was advocated in the High Court whereas the Court of Appeal emphasised the limited and procedural nature of the right. The House of Lords decision in Phelps was then used to highlight these differences. In the Court of Appeal judgment there seems implicit the idea that the large policy content inherent in education places judicial scrutiny of the right effectively beyond reach. In marked contrast the New Zealand High Court and British House of Lords appear keenly aware of the need for the right to be substantially enforceable. As statutorily prescribed rights are at stake it is simply a matter of interpretation for the courts to give substance and meaning to the right.

This article then addressed the ability of the legal system to enforce the right. It noted that the explicit language of the Education Act 1989 leant itself to judicial interpretation, and that the words

142 As is the stated aim of the SE2000 policy.

143 See $S$ v Attorney-General, above n 90, para 58.

144 Geuther, above n 128, 650 - it is unlikely that such 'small' issues will sway people's voting, if they are addressed by political parties in the first place. This emphasises the importance of judicial remedies in such areas. 
themselves belied the argument that no such recourse to the courts was ever intended. The practical difficulties that the SE2000 policy presented with both its centralised and devolved aspects were not in themselves reasons to deny the opportunity for judicial review. The general trend in New Zealand education policy, following "Tomorrow's Schools" is to devolution to the school level. If enforcement of the right to education had been devolved to the community as well, it would be expected that this would be explicitly stated. In any case it can hardly be said that the Minister retains no control of or responsibility for the positive obligation to provide education. The fact that certain aspects of the SE2000 policy remain centralised points even more strongly to the ability to judicially review decisions made in the area.

Following Daniels the law has been left in the unhappy state with a limited right to education and a corresponding lack of ability to enforce it effectively. The plaintiffs in Daniels may still have been awarded judicial review on technical grounds, yet the decision should be seen as a defeat of the right to education and the ability to enforce it. There is, however, still possibly scope for support of the right. If the facts in Phelps presented themselves in New Zealand it is likely that damages would also be awarded. This inconsistency is obscure. The right to education should be able to be protected and enforced at an earlier stage rather than waiting till a claim of negligence can be sustained. Perhaps education should be recognised as going beyond a social right and be protected as a civil and political right before the Government finds itself defending negligence claims. Accordingly, the ability to judicially review decisions made under the SE2000 policy is an appropriate remedy, and one that will make the right to education both effective and beneficial. 